\title{
Antimicrobial Action and Biopreservation by Autochthonous Lactic Acid Bacteria of Fish
}

\author{
Sutapa Sanyal ${ }^{*}$, Arnab Chatterjee \\ Department of Zoology, Krishnagar Govt College, Krishnagar, West Bengal, PIN-741101, India
}

Received December 8, 2020; Revised January 21, 2021; Accepted February 24, 2021

\section{Cite This Paper in the following Citation Styles}

(a): [1] Sutapa Sanyal, Arnab Chatterjee, "Antimicrobial Action and Biopreservation by Autochthonous Lactic Acid Bacteria of Fish," Advances in Zoology and Botany, Vol. 9, No. 2, pp. 37 - 44, 2021. DOI: 10.13189/azb.2021.090201.

(b):Sutapa Sanyal, Arnab Chatterjee (2021).Antimicrobial Action and Biopreservation by Autochthonous Lactic Acid Bacteria of Fish. Advances in Zoology and Botany, 9(2), 37 - 44. DOI: 10.13189/azb.2021.090201.

Copyright $\bigcirc 2021$ by authors, all rights reserved. Authors agree that this article remains permanently open access under the terms of the Creative Commons Attribution License 4.0 International License

\begin{abstract}
The purpose of this research was to assess native Lactic Acid Bacteria (LAB) for antimicrobial activities in relation to fish preservation. LAB were isolated from intestine of Oreochromis sp. Listeria monocytogenes, being a big microbial hazard of fresh as well as preserved fish food, was chosen against LAB antimicrobials. In the present study sixteen LAB like isolates from fish intestine were judged for their anti-listeria activities by agar well diffusion assay. Thirteen of them were antagonized Listeria monocytogenes (ATCC 657) by creating inhibition zone in nutrient agar plate. Antagonistic activities with inhibitory zones but not with growth circles clearly marked that inhibition was due to antimicrobials but not for competitive exclusion. LAB like bacteria in different forms like live cells, cell-free supernatant, alkaline cell- free supernatant and heated cell-free supernatant conferred antibacterial activities. No acid and hydrogen peroxide inhibition was reported. Except few, most of the alkaline and catalase treated culture supernatant when being heated to $90^{\circ} \mathrm{C}$ exhibited strong antagonism against the pathogenic strain. Susceptibility of Listeria monocytogenes to LAB antimicrobials seemed to be caused by both thermostable and thermolabile compounds and could be practiced in fisheries industry for food hygiene and also as biopreservatives.
\end{abstract}

Keywords Antimicrobials, Biopreservatives, LAB, Listeria moocytogenes, Thermolabile, Thermostable

\section{Introduction}

Recently demand for fish food is very high because of high quality proteins, usaturated fatty acids, vitamins and minerals [1]. Pathogen propagation through fish is a big threat [1]. Fresh fish is easily spoiled food compared to other food items. Owing to cross contamination by microbes from different sources, fishery products deteriorate very fast after cropping [2]. Listeria monocytogenes being food borne bacteria imposes a sententious health risk to human as a causative agent for listeriosis [2]. Fish could be infected by Listeria from its natural environments [2]. Processing and composing practices are the two main roots of Listeria entry in fish $[1,3]$. Listeria monocytogenes is considered as a hazard in food industry being pervasive, stress resistant, enduring, and psychro- and halotolerant [4] potentiality. Further, resistance to different antibiotics increases its threat $[5,6]$. Moreover, the situation becomes worst as Listeria monocytogenes remains alive and also flourish during handling and marketing of fish. [7] and [8] revealed low incidence of Listeria in freshwater fishes of India. [9] reported infrequent instances of Listeriosis in India. On contrary, [10-13] reported contamination of Listeria monocytogenes in fresh shell fishes as well as in fresh fin fishes from India. Listeria monocytogenes infected fish may impose a huge health risk to the Indian people as fish is an important part of diet for them.

Proper control measures of pathogenic microbes are important due to their role in health complications and food spoilage. Eradication and minimization of pathogenic and spoilage flora normally done by exercising different preservation techniques to obtain secure and 
sound products. Currently preservation strategies of biological origin have been flourished. Unfortunately in fishery trading appliances of microbial cultures and their antimicrobials are very rare. After effects of extraneous protective cultures on intrinsic microbes as well as on discernible attributes of fish are the main reason behind these limitations [14]. Lethal peptides synthesised by bacterial ribosome, could be administered as unique antimicrobials in food security, preservation and also to avoid spoilage $[15,16]$.

The aim of the present research paper was to place some basic data on the antimicrobial potentiality of the autochthonous microflora of fish to be applied in fisheries industry for food safety as well as for food preservatives. During the study fish intestine was screened for bacteriocins or killing peptides producing bacteria. Bacteriocins of LAB being GRAS (Generally Recognised as Safe) got the main focus in the present paper as natural food preservatives. In the present study, preliminary experiments were conducted to investigate possible inhibition of Listeria monocytogenes by culture and culture filtrates of LAB like bacteria.

\section{Materials and Methods}

\subsection{Sample Preparation}

Twenty live fish samples [Nile tilapia (Oreochromis niloticus)] were collected from local fish markets of Krishnagar and Santipur (bimonthly from March 2019 to February 2020). The collected samples were brought to the college laboratory in an ice box under full aseptic environment. Dissection, weighing, homogenization and serial dilutions of homogenates of the digestive tract contents of fish were done following $[17,18]$. Collection to investigation of fish was done within the time limit of 6 hrs.

\subsection{Bacterial Culture and Isolation}

Standard spread plate count method [19] at $35^{\circ} \mathrm{C}$ for 24 hrs on de Man, Rogosa, and Sharpe (MRS) Lactocilli agar plates was done for the determination of LAB like bacteria in anaerobic gas chamber. Bacteria with distinct morphologies from MRS agar plates were streaked aseptically several times on freshly prepared MRS Agar plates to obtain pure isolates.

Listeria monocytogenes (ATCC 657) was obtained from American Tissue Type Culture Collection (ATCC), Hi Media Laboratories Ltd., Mumbai, India. The food spoilage bacteria was then inoculated on non selective media like nutrient agar plate and incubated at $35^{\circ} \mathrm{C}$ for 24 hrs. Its growth was confirmed further on respective selective agar i.e. Listeria Selective Agar Base with Listeria Selective Supplement for Listeria. Agar well diffusion method $[20,21]$ was used to observe inhibitory actions of different LAB like isolates against Listeria monocytogenes (ATCC 657).

\subsection{Antibacterial Inhibition VS. Incubation Time}

The effect of incubation time versus antibacterial activity was studied by inoculating MRS broth with LAB like bacteria from MRS agar plates. Broth cultures were incubated separately at $35^{\circ} \mathrm{C}$ for 24 hrs and 48 hrs in anaerobic condition. $50 \mu \mathrm{l}\left(10^{9} \mathrm{CFU} / \mathrm{ml}, \mathrm{CFU}=\right.$ colony forming unit) of indicator pathogenic bacteria [22], from 24 hrs nutrient broth, were spread on nutrient agar plates. Nutrient agar palates were then pierced with wells of approximately $0.5 \mathrm{~mm}$ diameter. $50 \mu \mathrm{l}$ [23] concentrations of LAB like bacteria containing $10^{9} \mathrm{CFU} / \mathrm{ml}[22]$ from respective hrs of MRS broth cultures were poured into the well and then incubated at $35^{\circ} \mathrm{C}$ for $24 \mathrm{hrs}$.

\subsection{Bacteriocinogenic Activity of CFS}

LAB like bacterial isolates from 48 hrs MRS Broth cultures, after incubation, were subjected to centrifugation at $8000 \mathrm{~g}$ for $10 \mathrm{~min}$ at $4^{\circ} \mathrm{C}$ [24] to eliminate cells from the growth medium and to obtain unrefined cell-free supernatant (CFS). Filtration [24] of the unprocessed supernatants was performed through syringe-driven filter membranes $[0.20 \mathrm{~mm}$ pore size] to eradicate any remaining bacterial cell. The bacteriocin-like compound's activity was carried out by standard well diffusion method for filtered CFS. Cell free supernatants $(50 \mu \mathrm{l})$ of different LAB like isolates [23] were added in wells on nutrient agar plates which were formerly spread with $50 \mu \mathrm{L}$ of indicator strain. The nutrient agar plates were incubated for $24 \mathrm{hrs}$ at $35^{\circ} \mathrm{C}$.

\subsection{Antimicrobial Activity of Variously Treated CFS}

\subsubsection{Removal of Organic Acid}

To get rid of the effect of organic acids, $\mathrm{pH}$ of the filtered CFS was calibrated to 9 using $1(\mathrm{M}) \mathrm{NaOH}$ solution [25] and then inhibitory activity of that alkaline CFS (ACFS) was analysed against the indicator strain, Listeria monocytogenes (ATCC 657) by standard well diffusion method.

\subsection{2. $\mathrm{H}_{2} \mathrm{O}_{2}$ Elimination}

The alkaline CFS was treated with catalase (ACCFS) [24] and evaluated further for antimicrobial activity.

\subsubsection{Heat Sensitivity Testing}

Alkaline and catalase treated CFS was incubated at $90^{\circ} \mathrm{C}$ for $10 \mathrm{~min}$ [22], and then inhibitory activity of that CFS (HACCFS) was inspected against the indicator strain by standard well diffusion method.

The diameters of the inhibition zones were measured following [26]. 


\section{Results}

Round, small non pigmented and white to cream coloured colonies were primarily chosen from MRS agar surface. Isolates with LAB attributes like Gram-positive, rod shaped structure, catalase-positive were selected. Sixteen distinct LAB like isolates were maintained in 5 sets (A Series, E Series, F Series, G Series and H Series). Combative activities of sixteen $\mathrm{LAB}$ like isolates were represented through Table 1. Agar spot evaluation exhibited inhibitory zones relating antimicrobial compounds, no growth circles were detected (Figure 1,2,3). Furthermore, anti-listeria action was found to be greater at 48 hours than 24 hrs respectively (Figure 2). The relationship of the inhibitory activity with the incubation time clearly showed that most of the isolates effectively had reached their log phase of growth at 48 hrs and inevitably produced optimum antimicrobials.

Table 1. Antibiogram of LAB like isolates of fish against the tested indicator strainListeria monocytogenes (ATCC 657)

\begin{tabular}{|c|c|c|c|c|c|c|c|}
\hline \multirow[t]{3}{*}{ LAB } & \multicolumn{7}{|c|}{ Listeria monocytogenes } \\
\hline & \multirow{2}{*}{$\begin{array}{c}\begin{array}{c}\text { Effect of } 24 \text { hrs } \\
\text { incubated LAB } \\
\text { culture }\end{array} \\
\begin{array}{c}\text { Antimicrobial } \\
\text { effect of cell }\end{array}\end{array}$} & \multicolumn{6}{|c|}{ Effect of 48 hrs incubated LAB culture } \\
\hline & & $\begin{array}{l}\text { Antimicrobial } \\
\text { effect of cell }\end{array}$ & Crude CFS & Filtered CFS & $\begin{array}{l}\text { Neutralized } \\
\text { CFS }\end{array}$ & $\begin{array}{c}\text { Neutralized CFS+ } \\
\text { catalase }\end{array}$ & $\begin{array}{c}\text { Neutralized } \\
\text { CFS+catalase+ } \\
\text { heat treatment }\end{array}$ \\
\hline A1 & - & + & + & + & + & + & - \\
\hline A2 & - & + & + & + & + & + & + \\
\hline A3 & - & - & - & - & - & - & - \\
\hline A4 & - & - & - & - & - & - & - \\
\hline A5 & - & + & + & + & + & + & - \\
\hline E1 & + & + & + & + & + & + & + \\
\hline E2 & - & + & + & + & + & + & + \\
\hline E3 & - & + & - & - & - & - & - \\
\hline F1 & - & + & + & + & + & + & + \\
\hline F2 & - & + & - & - & - & - & - \\
\hline F3 & - & + & + & + & + & + & + \\
\hline G1 & - & + & + & + & + & + & + \\
\hline G2 & - & + & + & + & + & + & + \\
\hline H1 & + & + & + & + & + & + & + \\
\hline $\mathrm{H} 2$ & - & - & - & - & - & - & - \\
\hline H3 & + & + & + & + & + & + & + \\
\hline
\end{tabular}

$+=$ Growth occurred

-= No Growth

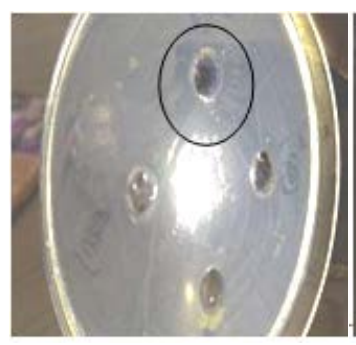

Figure 1.a)

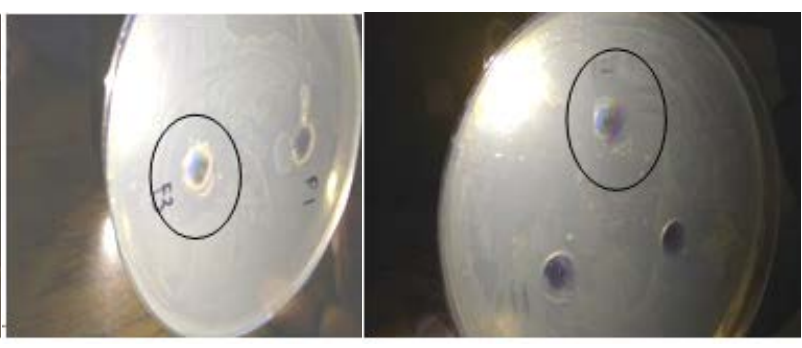

Figure 1.b)

Figure 1.c)

Figure 1. $[\mathbf{a}+\mathbf{b}+\mathbf{c}]$ Inhibitory Zones of LAB like bacteria in Agar Diffusion Method 
68.75\% CFS from LAB like bacteria was found to be effective (Table 1) against Listeria monocytogenes (ATCC 657). Filtered CFS after being alkaline with $\mathrm{NaOH}$ and treated with catalase remained successful (Table 1) against Listeria monocytogenes (ATCC 657). The data advocated that organic acids and hydrogen peroxide were not liable for inhibition of Listeria
monocytogenes(ATCC 657) (Table 1 and Figure 3).

Activities of major LAB CFS remained durable at $90^{\circ} \mathrm{C}$ after 10min of incubation. However, limited decrease in inhibition zone was detected after being heated at $90^{\circ} \mathrm{C}$ for 10 min as compared to inhibition zone of cell-culture or alkaline CFS (Figure 4a to 4e).

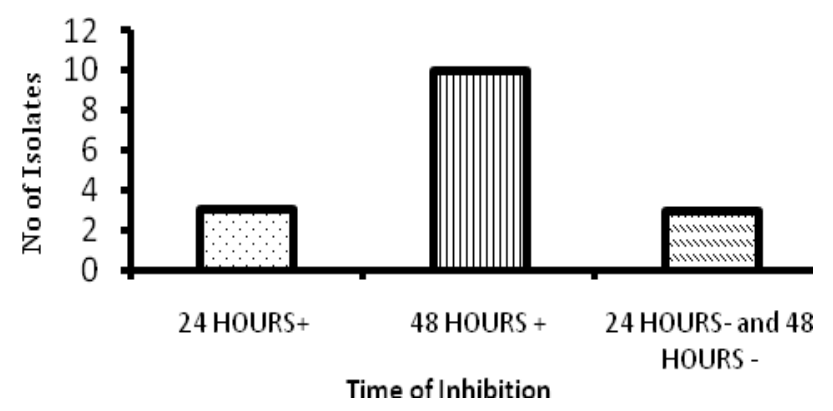

Figure 2. Effect of Incubation time on Inhibitory activities of LAB

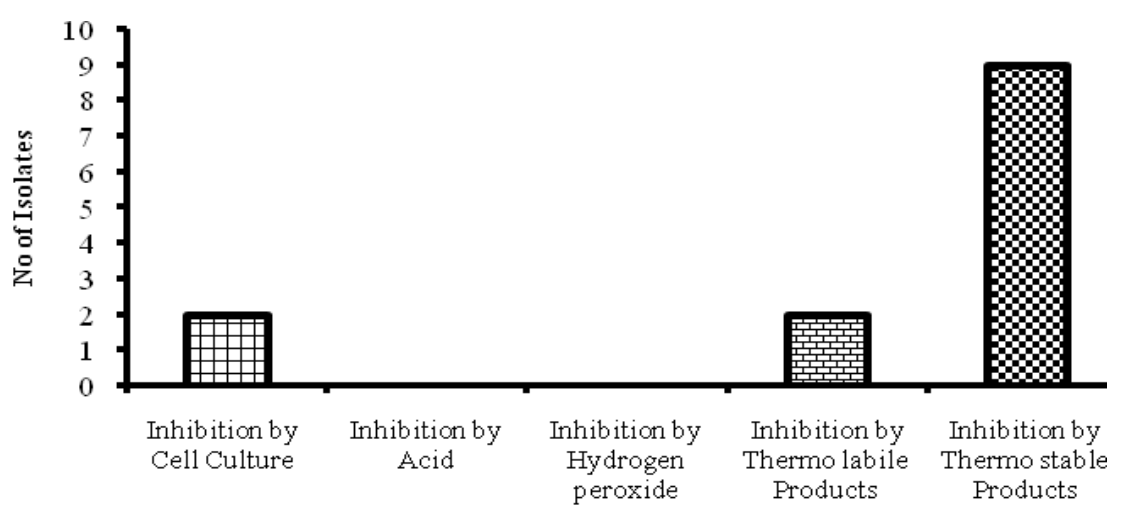

Types of Inhibitin

Figure 3. Diverse mode of Antilisterial Activities of LAB

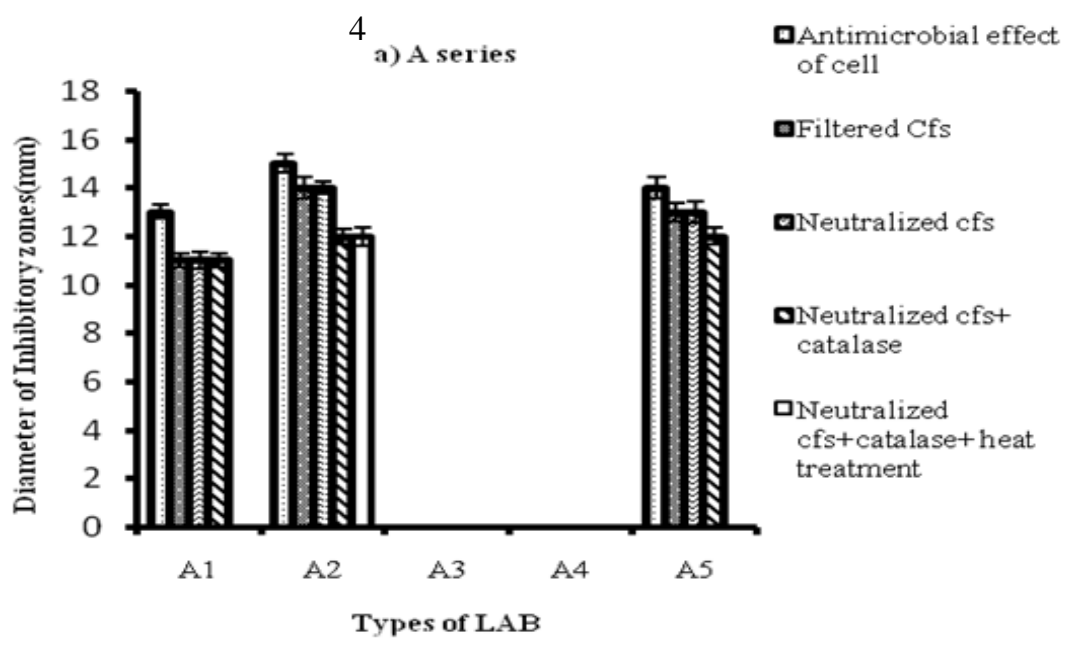



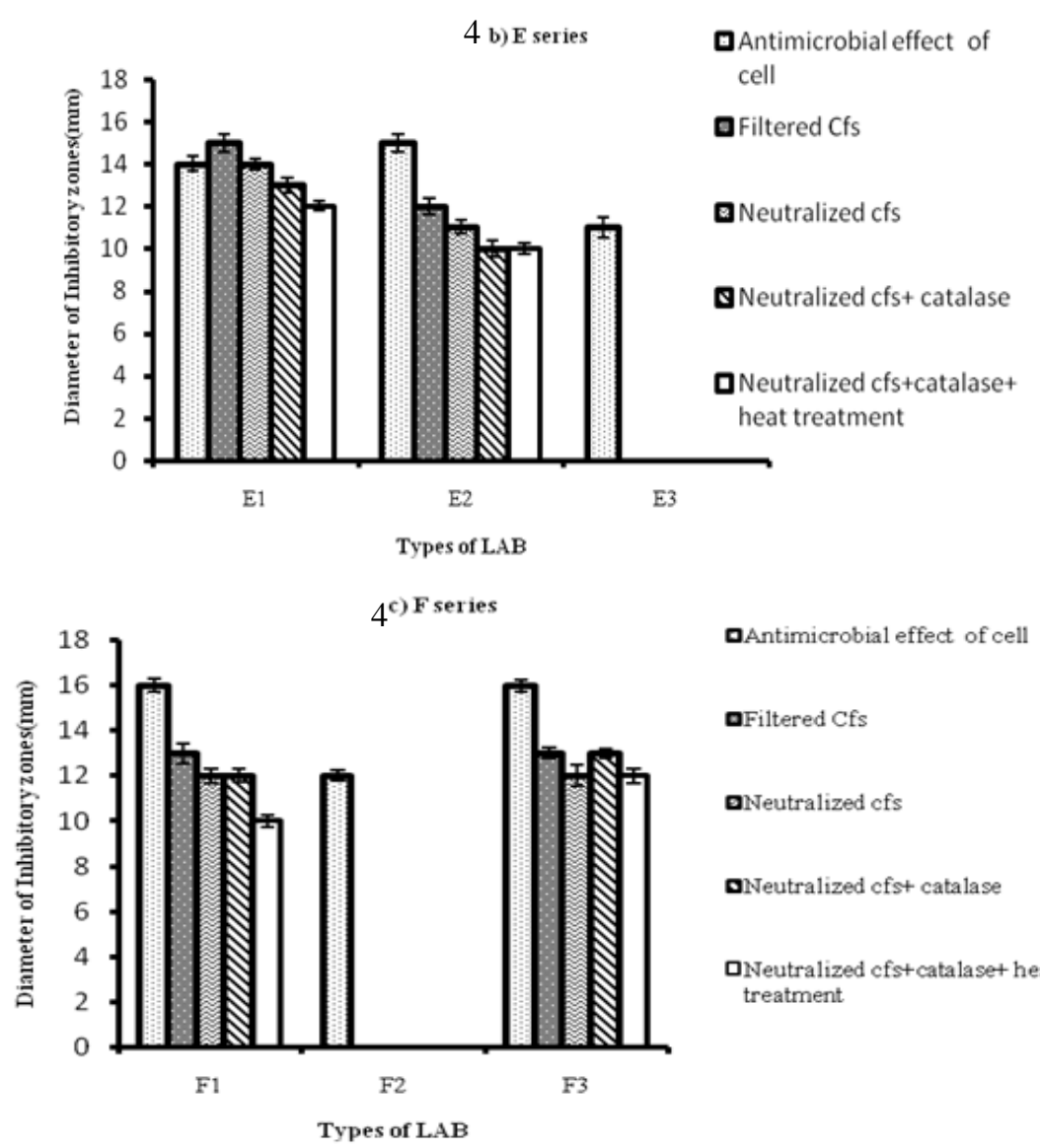

-Antimicrobial effect of cell

QFiltered Cfs

Deutralized cfs

Deutralized cfst catalase

QNeutralized cfstcatalase+ heat treatment

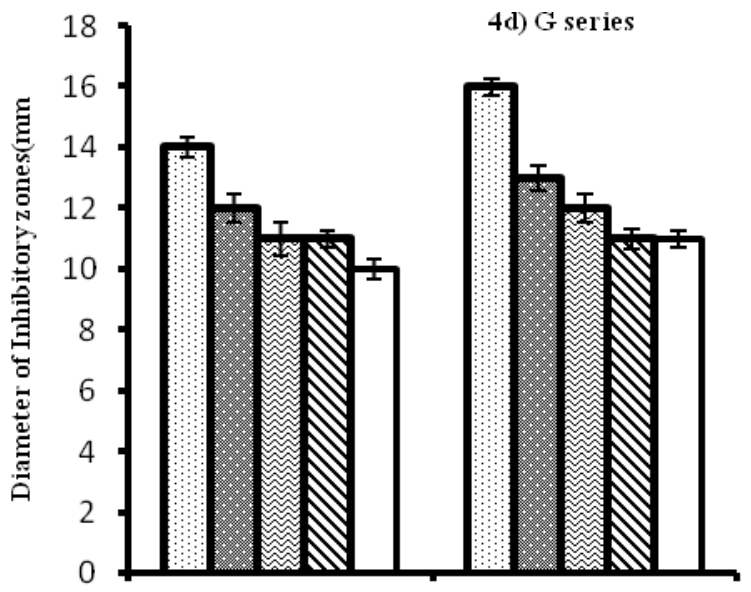

- Antimicrobial effect of cell

Filtered Cfs

DNeutralized cfs

-Neutralized cfst catalase

QNeutralized cfstcatalase+ heat treatment

G1

G2

Types of LAB 

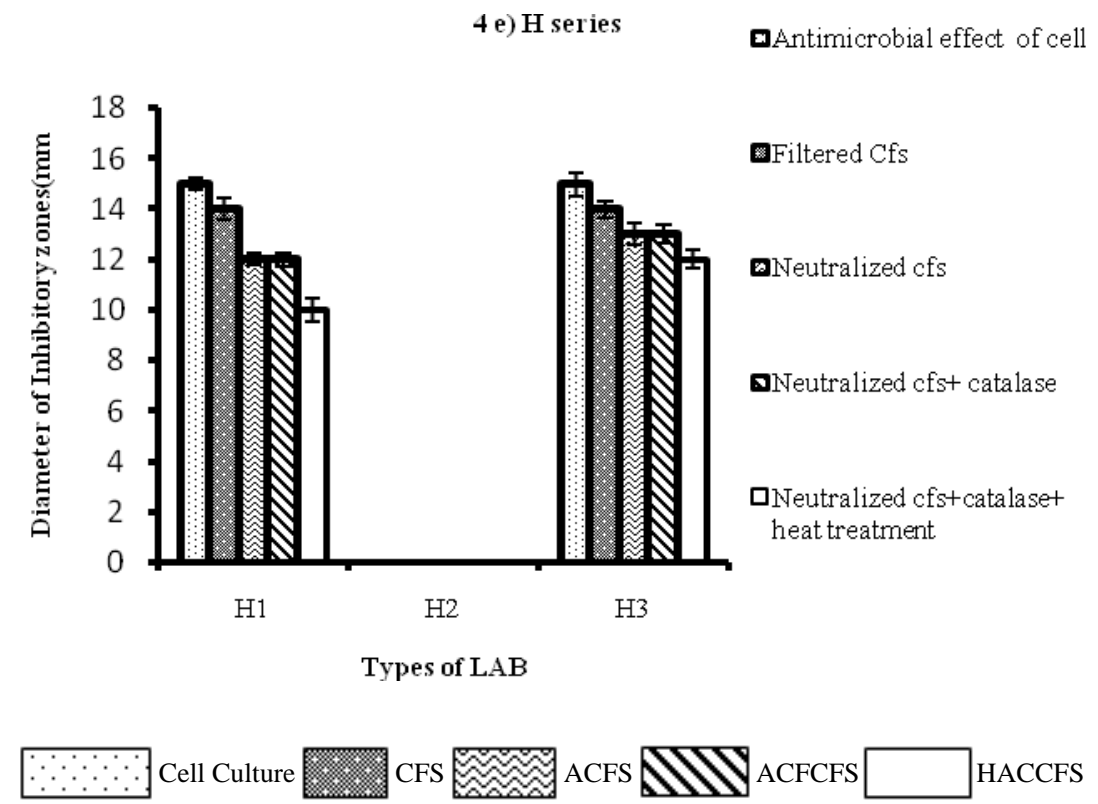

Figure 4. Antilisterial activity exhibited by inhibitory zones of different diameters (mean $\pm \mathrm{SE}, \mathrm{n}=5$ ) of individual LAB strains against Listeria monocytogenes (ATCC 657) (a), A series(b), E Series (c), F Series (d), G Series (e), and H Series

Thus thermostable products, probably proteins were reported as most potent inhibitory agent against Listeria monocytogenes. Few thermolabile products were also found to be impressive against Listeria monocytogenes. Our results further revealed that antimicrobials produced by nine LAB isolates (Table 1 and Figure 3 ) furnished thermotolerant and alkaline $\mathrm{pH}$ secured attributes. Two LAB like bacteria generated antagonistic activity towards Listeria monocytogenes exclusively in theform of live cells (Table 1 and Figure 3). Moreover, thermolabile inhibition against Listeria was also proclaimed by two intestinal LAB isolates (Table 1 and Figure 3).

\section{Discussion}

The study culminated extraction and execution of antibacterial activity of LAB like bacteria from Tilapia.The present paper reported divergent susceptibility of a single strain of Listeria monocytogenes (ATCC 657) to antilisterial compounds produced by different LAB like bacteria isolated from fish intestine. Agar spot method with clean inhibitory zones of different diameters indicated synthesis of antimicrobials but not competitive exclusion as reason of restrains actions. Impact of growth conditions on inhibitory activity revealed that, time played an important role in cell growth as well as in antimicrobial activity. Most of the antimicrobials of LAB were sufficiently opposed gram positive Listeria monocytogenes. This further confirmed the view of [27] that bacteriocins wipe out closely related bacteria. Detention of the strength of both thermostable and thermolabile antimicrobials at alkaline $\mathrm{pH}$ could not approve the antilisterial compounds of the present study as niscin[28]or enterocin [29] like bacteriocins. Moreover, heat resistant and high $\mathrm{pH}$ tolerance capacity stipulated the unspecified thermostable products as pediocin [30]. Furthermore, some undefined thermolabile compounds with high $\mathrm{pH}$ resilience elicited the inhibition to Listeria monocytogenes. Some of the antilisterial effect seemed to be caused by substances connected with live cells. These strains or their antimicrobials thus show some aptitude as fish preservatives in the fishery industry. Biopreservation with bacteriocins are always preferred as chance of entry of immune genes of bacteriocins from protective strains to pathogenic bacteria is high through conjugation or transposon as genes and immune gene of bacteriocins exist on the same plasmid or in adjacent regions of a chromosome [31].

\section{Conclusions}

The concept of the research is aspiring as autochthonus LAB like strains or their bacteriocins are enforced to prolong storage life of fish which could depreciate the proportion of change of microbial ecosystem as well as organoleptic modifications of the fish product. Isolated LAB like strains being probiotics would perform as curative, contraceptive and additives in buyer's fitness. However, LAB like isolates should be investigated for biogenicamines production and for multiple antibiotic resistances. The paper further emphasized application of protein like thermolabile and thermostable products over protective culture for storage quality improvement of fish. Protein like thermolabile and thermostable products of the research work could be a replacement to antibiotics in fish industry. However, investigation into resistance of protein 
like antilisterial compounds is needed. Moreover, being proteins these antimicrobials are safe food supplements as digested by proteases of the gastrointestinal system. Finally in vivo application of antimicrobials in fish is required for inspecting the consequences of chemical and physical conditions of food on efficacies of antilisterial products.

\section{Acknowledgements}

This investigation was supported by a grant for scientific research from West Bengal State DST (File No.:281(Sanc)/ST/P/S\&T/1G-52/2017 Dated 27/03/2018).

\section{REFERENCES}

[1] M. Jami, M. Ghanbari, M. Zunabovic, K. J. Doming and W. Kneifel. Listeria monocytogenes in aquatic food products-a review, Comprehensive Reviews In Food Science and Food Safety, 13: 798-813, 2014.

[2] EFSA (European Food Safety Authority) and ECDC (European Centre for Disease Prevention and Control). The European Union summary report on trends and sources of zoonoses, zoonotic agents and food-borne outbreaks in 2011, EFSA Journal, 11(4), 3129:1-250, 2013. Online Available from

http://www.efsa.europa.eu/en/efsajournal/pub/3129.htm. Accessed 2014 April 25.

[3] P. Gambarin, C. Magnabosco, M. N. Losio, E. Pavoni, A. Gattuso, G. Arcangeli and M. Favretti. Listeria monocytogenes in Ready-to-eat seafood and potential hazards for the consumers, International Journal of Microbiology, Article ID 497635, p. 10, 2012.

[4] H. P. R. Seeliger and D. Jones. Listeria, In P. H. A. Sneath, N. S. Mair, M. E. Sharpe and J. G. Holt (ed.), Bergey's manual of systematic bacteriology, vol. 2, p. 1235-1245, Williams and Wilkins, Baltimore, Md, 1986.

[5] C. G. Gahan and C. Hill. Gastrointestinal phase of Listeria monocytogenes infection, Journal of Applied Microbiology, 98(6):1345-1353, 2005.

[6] M. Schuppler and M. J. Loessner. The opportunistic pathogen Listeria monocytogenes: pathogenicity and interaction with the mucosal immune system, International Journal of Inflammation, Volume 2010, Article ID 704321, 12 pages, 2010. Online Available from https://doi.org/10.40 $61 / 2010 / 704321$

[7] I. Karunasagar and I. Karunasagar. Listeria in tropical fish and fishery products, International Journal of Food Microbiology, 62, 177-81, 2000.

[8] V.S. Parihar, S.B. Barbuddhe, M. Danielsson-Tham and W. Tham. Isolation and characterization of Listeria species from tropical seafoods, Food Control,19: 566-569, 2008.

[9] B. Dhanashree, I. Karunasagar and I. Karunasagar.
Incidence of Listeria spp. in fish and shellfish around Mangalore, Journal of Food Science and Technology,9: 49-51, 1999.

[10] I. Karunasagar, K. Segar, I. Karunasagar and W. Goebel. Incidence of Listeria species in tropical seafoods, Listeria 1992, Abstract 155, XI International Symposium on Problems of Listeriosis, Copenhagen, 11-14 May 1992.

[11] G. Jayasekaran, I. Karunasagar and I. Karunasagar. Incidence of Listeria sp. in tropical fish, International Journal of Food Microbiology, 31, 333-340, 1996.

[12] R. Aurora, A. Prakash and S. Prakash. Virulence-Associated Genes Profile of Listeria monocytogenes Isolated from Milk and RTE Indigenous Milk Products in Agra City, D.E.I., Journal of Scientific and Engineering Research, 14(1): 25-33, 2007.

[13] R. Aurora, A. Prakash and S. Prakash. Geneotypic characterization of Listeria monocytogenes isolated from milk and ready-to-eat indigenous milk products, Food Control, 20: 835-839,2009.

[14] F. Leroi. Biopreservation of lightly preserved seafood products, INFOFISH International, 4, 41-46,2011.

[15] J. Cleveland, T. J. Montville, I. F. Nes and M. L. Chikindas. Bacteriocins: Safe, natural antimicrobials for food preservation, International Journal of Food Microbiology,71, $1-20,2001$.

[16] C. Knoll, B. Divol and M. Toit. Genetic screening of lactic acid bacteria of oenological origin for bacteriocin-encoding genes, Food Microbiology, 25, 983-991. 2008.

[17] N. Buras, L. Duek, S. Niv, B. Hepher and E. Sandbank. Microbiological aspects of fish grown in treated wastewater, Water Research, 21(1): 1-10, 1987.

[18] S. Sanyaland S. Banerjee. Transferable drug resistant coliforms in fish exposed to sewage, Archives of Polish fisheries, 21, 29-39, 2013.

[19] APHA. Standard Methods for the Examination of Water and Wastewater, 20th Edition, APHA (American Public Health Association), Washington, USA, 1998.

[20] J. G Cappuccino and N. Sherman. Microbiology a Laboratory Manual (Vol 1), New York, Benjamin Cumming, 2002.

[21] J. L. Balcazar, D. Vendrell, I. de Blas, I. Ruiz-Zarzuela, J. L. Muzquiz and O. Girones. Characterization of probiotic properties of lactic acid bacteria isolated from intestinal microbiota of fish, Aquaculture, 278, 188-191, 2008. http://dx.doi.org/10.1016/j.aquaculture.2008.03.014.

[22] I. Složilová, S. Purkrtová, M. Kosová, M. Mihulová,E. Šviráková and K. Demnerová. Antilisterial Activity of Lactic Acid Bacteria against ListeriamonocytogenesStrains Originating from Different Sources, Czech Journal of Food Science, 32, 2: 145-151, 2014.

[23] R. Jini, H. C. Swapna, A. K. Rai, R. Vrinda, P. M. Halami, N. M. Sachindra and N. Bhaskar. Isolation and characterization of potential lactic acid bacteria (lab) from freshwater fish processing wastes for application in fermentative utilisation of fish processing waste, Brazilian Journal of Microbiology, 42: 1516-1525, 2011. 
[24] L. I. Schelegueda, M. Vallejo, M. F. Gliemmo, E. R. Marguet and C. A. Campos. Synergistic antimicrobial action and potential application for fish preservation of a bacteriocin produced by Enterococcus mundtii isolated from Odontesthes platensis, LWT- Food Science and Technology, 64(2015): 794-801, 2015.

[25] N. Udhayashree, D. Senbagam, B. Senthilkumar, K. J. Nithya and R. Gurusamy. Production of bacteriocin and their application in food products, Asian Pacific Journal of Tropical Biomedicine, 2(1): 406-410, 2012.

[26] M. Rammelsberg and F. Radler. Antibacterial polypeptides of Lactobacillus species, Journal of Applied Bacteriology, 69:177-184, 1990.

[27] T. R. Klaenhammer. Genetics of bacteriocin produced by lactic acid bacteria, FEMS Microbiological Review, 12(1-3): 39-85, 1993. Online Available from doi: 10.1111/j.1574-6976.1993.tb00012.x.
[28] W Liu and J. N. Hansen. Some chemical and physical properties of nisin, a small-protein antibiotic produced by Lactococcus lactis, Applied and Environmental Microbiology, 56: 2551-2558, 1990.

[29] W. Jennes, L. M. T. Dicks and D. J. Verwoerd. Enterocin 012, a bacteriocin produced by Enterococcus gallinarum isolated from the intestinal tract of ostrich, Journal of Applied Microbiology, 88(2): 349-57, 2000. Online Available from doi: 10.1046/j.1365-2672.2000.00979.x.

[30] D. Drider, G. Fimland, Y. Héchard, L. M. McMullen and H. Prévos. The continuing story of class IIabacteriocins, Microbiology and Molecular Biology Reviews, 70: 564-582, 2006.

[31] S.C. Yang, C. Hunglin, C. T. Sung and J. Youfang. Antibacterial activities of bacteriocins: application in foods and pharmaceuticals, Frontiers in microbiology, 5, 241, 2014. 